\title{
STRENGTH AND DURABILITY PROPERTIES OF COPPER SLAG ADMIXED CONCRETE
}

\author{
Binaya Patnaik ${ }^{1}$, Seshadri Sekhar. ${ }^{2}$, Srinivasa Rao $^{3}$ \\ ${ }^{1}$ Research Scholar, Civil Engineering Department, GITAM University, Hyderabad, India \\ ${ }^{2}$ Professor, Civil Engineering, Department, GITAM University, Hyderabad, India \\ ${ }^{3}$ Professor, JNTU, College of Engineering, Hyderabad, India
}

\begin{abstract}
An experiment was conducted to investigate the strength and durability properties of concrete having copper slag as a partial replacement of sand (fine aggregate) and results have been presented in this paper. Two different types of Concrete Grade (M20 \& M30) were used with different proportions of copper slag replacement (0 to 50\%) in the concrete. Strength \& Durability properties such as Compressive Strength, Split Tensile Strength, Flexural Strength, Acid Resistivity and Sulphate Resistivity were evaluated for both mixes of concrete. Test results shows that the strength properties of concrete has improved having copper slag as a partial replacement of Sand (upto 40\%) in concrete however in terms of durability the concrete found to be low resistant to acid attack and higher resistance against Sulphate attack.
\end{abstract}

Keywords: Copper Slag, Durability, Compressive Strength, Partial Replacement, Flexural Strength, Split Tensile Strength

\section{INTRODUCTION}

River Sand is common form of fine aggregate used in the manufacturing of concrete. However because of increased cost and large scale depletion of sources alternatives for river sand are being considered. There have been many alternative materials with similar physical \& chemical properties of Sand found (Lime stone waste, marble powder, furnace slag and welding slag, stone dust etc.) and research have being carried out to check the suitability of its use as partial replacement of sand. Copper Slag is an industrial byproduct abundantly available near copper producing industries having similar physical \&chemical properties of Sand can be considered as an alternative to the river sand. This will help in resolving a major concern of industrial waste disposal along with decreased cost of construction.

\section{LITERATURE REVIEW}

Brindha et al studied the strength behavior of concrete where sand was partially replaced with Copper Slag in the concrete manufacturing process. The strength was found to be increasing till $40 \%$ of sand replacement with copper slag after which the strength was found to be decreasing. Brindha and Nagan studied the durability properties of copper slag admixed concrete and found that the concrete with copper slag has less resistance to the H2So4 solution than the control concrete. Saveria Monosi et al studied impact of Foundry Sand in Mortars and Concrete and found structural mortar and concrete can be manufactured with UFS as partial replacement of natural sand. A suitable recycling of the discarded foundry sand as building construction material was suggested. Ishimaru et al used class II fly ash and copper slag as fine aggregates in concrete and found that the by substituting copper slag or class II fly ash up to $20 \%$ (in volume) as fine aggregates the best results achieved in terms of compressive strength. Chandana Sukesh et al investigated the impact of using quarry dust as a partial replacement of sand in concrete and found an improved performance of concrete in terms of compressive strength. Sreekrishnaperumal Thanga Ramesh et al used welding slag and furnace slag as partial replacement for sand and found a better performance towards compressive strength. As per the experimental result, $10 \%$ of Furnace Slag \& 5\% of Welding Slag as sand replacement was very effective. Ion Dumitru et al did Field Trials Using Recycled Glass as Natural Sand Replacement and powdered glass as Cementitious Materials Replacement in Concrete pavement and found that recycled sand glass can be used to partially replace natural sand in concrete, producing concrete with at least equivalent fresh and hardened properties. Omar M. Omara et al used marble powder and limestone waste as partial replacement material for sand and found that compressive strength of the concrete increases with increase in the percentages of M.P additions at all curing ages. Al-Jabri et al used Cement by-Pass Dust (CBPD) and Copper Slag as partial replacement of cement in mortar preparation. The optimum strength achieved with 95\% cement $+5 \%$ CBPD mix and 1.5\% CBPD + 13.5 CS + $85 \%$ cement mix. Washington Almeida, Moura et al studied the strength properties of concrete when copper slag was used as a partial replacement of the sand and found an increased compressive, split tensile strength. It also showed a decreased carbonation depth which shows an improved durability quality. Binaya et al reported that sand can be partially replaced with copper slag in concrete manufacturing process and for M20 Grade mix the maximum strength can be attained with $40 \%$ of Copper 
Slag replacement. Binaya et al reported that when copper slag is partially replaced with sand in M30 Grade concrete, the coefficient of determination for 28 days \& 90 days compressive strength found to be 0.9753 and 0.9748 which indicates that the model has a good fit.

\section{EXPERIMENTAL DETAILS}

\subsection{Materials}

\subsubsection{Coarse Aggregate}

$20 \mathrm{~mm}$ size angular crushed granite metal having specific gravity of 2.6 and fineness modulus of 7.1 was used. Bulk Density in loose state and compacted state were found to be $1414 \mathrm{~kg} / \mathrm{m}^{3}$ and $1550 \mathrm{~kg} / \mathrm{m}^{3}$ respectively. The water absorption was $1.1 \%$.

\subsubsection{Fine Aggregate}

River sand having the sp.gravity of 2.6 and fineness modulus 2.4 was used. The Bulk Density in loose state and compacted state were found to be $1597 \mathrm{~kg} / \mathrm{m}^{3}$ and $1700 \mathrm{~kg} / \mathrm{m}^{3}$ respectively. The water absorption was $1.20 \%$.

\subsubsection{Cement}

53 Grade OPC having specific gravity of 3.094, fineness modulus of $4.62 \%$ and normal consistency of $32 \%$ was used. As per IS 4031-1988, various tests were conducted to check the quality of cement and confirmed to specifications of 12269-1987.

\subsubsection{Copper Slag}

Copper Slag with sp. gravity 3.47 and fineness modulus 3.3 was used. Bulk Density in loose state and compacted state was found to be $1898 \mathrm{~kg} / \mathrm{m}^{3}$ and $2024 \mathrm{~kg} / \mathrm{m}^{3}$ respectively. The water absorption was $0.24 \%$. As per the chemical analysis of Copper Slag, Silica content in Copper Slag was found to be $33.52 \%$.

\subsubsection{Test Specimens}

Test specimens consisting of cube specimens of size $150 \times 150 X 150 \mathrm{~mm}$ were casted and tested as per IS 516 and 1199.

\subsection{Mix Design}

Mix Design was done as per the code book, IS: $10262-$ 1979 and the amount of materials were calculated. Table 1.0 gives the quantities required for M20 and M30 grade of Concrete Mixes. The specimens were casted by replacing fine aggregate from $0 \% \& 40 \%$ with copper slag.

\subsection{Mixing, Demoulding and Curing}

For achieving a good concrete the most important factors are proper mixing and adequate curing which were followed during the casting process. Pan mixture was used for the mixing process and the mixing time was kept for 3-4 minutes. Demoulding was done after $24 \mathrm{hrs}$ of casting.
Concrete Cubes were thoroughly cured by using clean water.

\section{EXPERIMENTAL PROCEDURE}

\subsection{Compressive Strength}

$3000 \mathrm{KN}$ capacity Compression testing machine (CTM) was used to measure the compressive strength of concrete. As per IS: $516-1959$ [4], loading rate of $2.5 \mathrm{kN} / \mathrm{s}$ was applied. $150 \mathrm{~mm} \times 150 \mathrm{~mm}$ X $150 \mathrm{~mm}$ size cubes were used for the testing. Compressive Strength was measured at 28 and 90 days.

\subsection{Split Tensile Strength}

This test was carried out on a universal testing machine (UTM) of capacity $1000 \mathrm{kN}$. As per IS: 516-1959 [4] loading rate of $2.5 \mathrm{kN} / \mathrm{s}$ was applied. Cylinder specimens (size $150 \mathrm{~mm}$ diameter X $300 \mathrm{~mm}$ long) were used for this testing. Split Tensile Strength was measured at 28 and 90 days.

\subsection{Flexural Strength}

This test was carried out as per IS - 516:1964. Beam specimens of $100 \mathrm{~mm}$ x $100 \mathrm{~mm}$ x $500 \mathrm{~mm}$ were used for this testing. Flexural Strength was measured at 28 and 90 days.

\subsection{Durability}

\subsubsection{Test of Sulphate Resistance on Copper Slag}

\section{Admixed Concrete}

Sulphate resistance of concrete is determined by immersing test specimens of size $100 \times 100 \times 100 \mathrm{~mm}$ cubes in $10 \%$ sodium sulphate. The deterioration of specimens was presented in the form of percentage reduction in weight and percentage reduction in compressive strength of concrete specimens at 28 and 56days.

\subsubsection{Test of Acid Attack Copper Slag Admixed}

\section{Concrete}

Acid attack is determined by immersing test specimens of size $100 \times 100 \times 100 \mathrm{~mm}$ cubes in $10 \% \mathrm{H} 2 \mathrm{So} 4$ solution and $10 \% \mathrm{HCl}$ solution respectively. The deterioration of specimens was presented in the form of percentage reduction in weight and percentage reduction in compressive strength of concrete specimens at 28 and 56days.

\section{DISCUSSION OF RESULTS}

\subsection{Compressive Strength}

From the Tables 2.0, it can be observed that by partially replacing sand with copper slag up to $40 \%$, the compressive strength of concrete increased. For M20 Grade Mix Concrete (40\% of copper slag replacement), the compressive strength at $28 \& 90$ days were $41.05 \mathrm{~N} / \mathrm{mm} 2$ and $55.17 \mathrm{~N} / \mathrm{mm} 2$ compared with $36.8 \mathrm{~N} / \mathrm{mm} 2$ and 44.34 
$\mathrm{N} / \mathrm{mm} 2$ for the control mixture. For M30 Grade Mix Concrete $(40 \%$ of copper slag replacement), the compressive strength at $28 \& 90$ days were $47.41 \mathrm{~N} / \mathrm{mm} 2$ and $57.24 \mathrm{~N} / \mathrm{mm} 2$ compared with $41.16 \mathrm{~N} / \mathrm{mm} 2$ and 51.28 $\mathrm{N} / \mathrm{mm} 2$ for the control mixture. These variations are shown in fig 1.0. Copper Slag has a lower water absorption capacity when compared with Sand. The lower water absorption capacity causes increased free water content there by decrease in Compressive Strength. This further causes increase in the workability.

\subsection{Split Tensile Strength}

Split Tensile Strengths for M-20 and M-30 concrete are as shown in Table 3.0. For M20 Grade Mix Concrete (40\% of copper slag replacement) the 28 days and 90 days Split Tensile strength were $2.204 \mathrm{~N} / \mathrm{mm} 2$ and $2.58 \mathrm{~N} / \mathrm{mm} 2$ compared with $2.17 \mathrm{~N} / \mathrm{mm} 2$ and $2.3 \mathrm{~N} / \mathrm{mm} 2$ for the control mixture. For M30 Grade Mix Concrete (40\% of copper slag replacement), the 28 days and 90 days Split Tensile strength were $2.982 \mathrm{~N} / \mathrm{mm} 2$ and $3.67 \mathrm{~N} / \mathrm{mm} 2$ compared with 2.924 $\mathrm{N} / \mathrm{mm} 2$ and $3.3 \mathrm{~N} / \mathrm{mm} 2$ for the control mixture. They are also plotted pictorially as shown in fig. 2.0. The results shows that compared to control concrete the Copper slag mixed(40\%) concrete has higher Split Tensile strength the 28-Day and 90-Days.It was also observed that the, early strength gain for Copper slag admixed concrete is less compared to the control concrete. This property was observed for both M-20 and M-30 concrete.

\subsection{Flexural Strength}

The results of Flexural Strengths for M-20 and M-30 concrete are as shown in Table 4.0. For M20 Grade Mix Concrete (40\% of copper slag replacement) the 28 days and 90 days Flexural strength were $4.747 \mathrm{~N} / \mathrm{mm} 2$ and 5.74 $\mathrm{N} / \mathrm{mm} 2$ compared with $4.44 \mathrm{~N} / \mathrm{mm} 2$ and $5.31 \mathrm{~N} / \mathrm{mm} 2$ for the control mixture. For M30 Grade Mix (40\% of copper slag replacement), the 28 days and 90 days Flexural strength were $5.28 \mathrm{~N} / \mathrm{mm} 2$ and $6.41 \mathrm{~N} / \mathrm{mm} 2$ compared with 4.87 $\mathrm{N} / \mathrm{mm} 2$ and $5.83 \mathrm{~N} / \mathrm{mm} 2$ for the control mixture. They are also plotted pictorially as shown in fig. 3.0. The results show that at $28 \& 90$ days is Copper slag mixed (40\% replacement) concrete has a higher Flexural Strength than the control concrete.

\subsection{Durability}

\subsubsection{Acid attack of Concrete Specimens (H2SO4)}

\subsubsection{Loss of Weight (In \%) - $10 \%$ H2So4}

\section{Solution Immersion}

From table 5.0 it can be observed that for M20 grade mix the percentage loss of weight for controlled mix is $19.68 \%$ for 28 days, $22.35 \%$ for 56 days while for $40 \%$ of copper slag replacement the percentage loss of weight is $13.16 \%$ for 28 days, $14.92 \%$ for 56 days. For M30 grade mix the percentage loss of weight for controlled mix is $13.985 \%$ for 28 days, $17.01 \%$ for 56 days while for $40 \%$ of copper slag replacement the percentage loss of weight is $7.409 \%$ for 28 days, $11.27 \%$ for 56 days. The percentage weight loss is observed to be increasing in correspondence with time. The behavior is given in fig 4 .

\subsubsection{Loss of Compressive Strength (In \% ) - $10 \%$}

\section{H2So4 Solution Immersion}

From table 6.0 it can be observed that for M20 grade mix the percentage loss of compressive strength for controlled mix is $19.02 \%$ for 28 days, $38.21 \%$ for 56 days respectively while for $40 \%$ of copper slag replacement the compressive strength loss is $51.38 \%$ for 28 days, $64.99 \%$ for 56 days respectively. For M30 mix, the \% loss of compressive strength for controlled mix is $21.55 \%$ for 28 days, $39.19 \%$ for 56 days respectively while for $40 \%$ of copper slag replacement the compressive strength loss is $53.15 \%$ for 28 days, $67.14 \%$ for 56days respectively. The behavior is given in fig 5.

The test result indicates that the concrete with copper slag has lesser in resistance to the $\mathrm{H} 2 \mathrm{So} 4$ solution than the control concrete. Therefore, the following conclusions were made on acid attack. The concrete prepared with copper slag showed relatively higher mass change. Although both control and copper slag concrete suffered slight mass losses during the early periods, the overall loss in mass of the copper slag replaced specimens was much higher. All concrete specimens get affected by acid attack. The outer portion of cubes gets destroyed and there is a maximum reduction of $3 \mathrm{~mm}$ at all sides for all specimens. Control specimens showed higher resistance to acid attack than copper slag replaced specimens. So the conclusion is made that controlled specimen has higher resistance to acid attack compared to copper slag admixed concrete.

\subsubsection{Acid attack of Concrete Specimens $(\mathrm{HCl})$}

\subsubsection{Loss of Weight (In \%) - $10 \%$ HCl Solution}

\section{Immersion}

From table 5.0 it can be observed that for M20 grade mix the percentage loss of weight for controlled mix is $7.695 \%$ for 28 days, $10.03 \%$ for 56 days while for $40 \%$ of copper slag replacement the percentage loss of weight is $6.629 \%$ for 28 days, $8.83 \%$ for 56 days. For M30 grade mix the percentage loss of weight for controlled mix is $3.75 \%$ for 28 days, $6.64 \%$ for 56 days while for $40 \%$ of copper slag replacement the percentage loss of weight is $2.769 \%$ for 28 days, $3.73 \%$ for 56 days. The percentage weight loss is observed to be increasing in correspondence with time. The behavior is given in fig 6 .

\subsubsection{Loss of Compressive Strength (In \%) - $10 \%$}

\section{HCl Solution Immersion}

From table 6.0 it can be observed that for M20 grade mix the percentage loss of compressive strength for controlled mix is $8.23 \%$ for 28 days, $27.39 \%$ for 56 days respectively while for $40 \%$ of copper slag replacement the loss in compressive strength is $41.42 \%$ for 28 days, $53.25 \%$ for 56 
days respectively. For M30 grade mix controlled concrete the $\%$ loss of compressive strength is $11.13 \%$ for 28 days, $28.16 \%$ for 56 days respectively while for $40 \%$ of copper slag replacement the loss in compressive strength is $42.73 \%$ for 28 days, $61.13 \%$ for 56 days respectively. The behavior is given in fig 7.

The percentage loss is observed to be increasing in correspondence with time. Control specimens showed higher resistance to $\mathrm{HCl}$ acid attack than copper slag replaced specimens. Deterioration of concrete was not occurring due to $\mathrm{HCl}$ attack. There will not be any considerable reduction in mass due to $\mathrm{HCl}$ attack.

\subsubsection{Sulphate attack of Concrete Specimens (Na2So4)}

\subsubsection{Loss of weight (In \%) $\quad-10 \%$ Na2So4Solution Immersion}

Table 5.0 shows the percentage loss of weight is Nil. This shows that Copper slag admixed concrete have the resistance against $\mathrm{Na} 2 \mathrm{So} 4$ solution.

\subsubsection{Loss of Compressive Strength (In \%) - $10 \%$ Na2So4 Solution Immersion}

Table 6.0 shows the percentage loss of compressive strength is Nil. Deterioration of concrete was not occurring due to sulphate attack. There will not be any considerable reduction in mass due to sulphate attack.

\section{CONCLUSION}

- Cost of Concrete production reduces when Copper Slag is used as a fine aggregate in concrete.

- High toughness of Copper Slag attributes to Increased Compressive strength.

- Due to low water absorption, coarser (in nature than sand) and glassy surface of Copper slag the workability of Concrete increased substantially with increase of Copper Slag content in the concrete mixture.

- Use of copper slag helps in waste management and dumping industrial wastes.

- Copper Slag behaves similar to River Sand as it contains Silica ( $\mathrm{SiO} 2)$ similar to sand.

- Addition of Copper Slag increases the density of concrete thereby increasing the Self-weight.

- The water absorption of Copper Slag was measured to be $0.24 \%$ which is less than that of Natural Sand $(1.2 \%)$. Because of this Copper Slag would demand less water compared to sand in concrete mix. Hence as the Copper slag content increases in the concrete the free water content in concrete matrix also increases which leads to increased workability.

- The Compressive Strength of Concrete with partial replacement of Sand with Copper Slag up to $40 \%$ can be comparable with control mix. However with increased copper slag content there by increased free water content the compressive strength decreased.

- Acid resistance test showed that the concrete containing copper slag has a low resistance to $\mathrm{H} 2 \mathrm{So} 4$ and $\mathrm{HCl}$ solution than the control concrete

- Concrete with Copper slag as Partial replacement of Sand shows good resistance to sulphate attack.

\section{REFERENCES}

[1]. Brindha, D and Nagan, S (2010). "Utilization of copper slag as a partial replacement of fine aggregate". International Journal of Earth Sciences and Engineering, Vol.3, No.4, pp.579-585

[2]. D Brindha, S Nagan (2011). "Durability Studies on Copper Slag admixed concrete." Asian Journal of Civil Engineering (Building and Housing) Vol.12, No 5(2011). Page 563-578

[3]. Saveria Monosi, Daniela Sani and Francesca Tittarelli (2010). "Use of Foundry Sand in Cement Mortars and Concrete Production". The Open Waste Management Journal, Vol. 3, 18-25.

[4]. Ishimaru, K., Mizuguchi, H., Hashimoto, C., Ueda, T., Fujita, K. and Ohmi, M (2005). "Properties of copper slag and second class fly ash as a part of fine aggregate".Jounal of Society Material Science Japan, Vol. 54, No. 8, pp. 828833.

[5]. Chandana Sukesh, Katakam Bala Krishna, P. SriLakshmi Sai Teja, S.Kanakambara Rao (2013). "Partial Replacement of Sand with Quarry Dust in Concrete".(IJITEE), ISSN: 2278-3075, Vol.2,No 6. pp.254258.

[6]. Sreekrishnaperumal Thanga Ramesh, Rajan Gandhimathi, Puthiya Veetil Nidheesh, Shanmugam Rajakumar and Subramani Prateep kumar. "Use of furnace slag and welding slag as replacement for sand in concrete". International Journal of Energy and Environmental Engineering. Vol.4, No.3, pp.1-6.

[7]. Ion Dumitru, Tony Song, Bob Bornstein, Phillip Brooks and Justin Moss. "Field Trials Using Recycled Glass as Natural Sand Replacement and Powdered Glass as Cementitious Materials Replacement in Concrete Pavement". Third international conference on sustainable construction materials and technologies.

[8]. Omar M. Omara, Ghada D. Abd Elhameedb, Mohamed A. Sherifa, Hassan A. Mohamadienc (2012). "Influence of limestone waste as partial replacement material for sand and marble powder in concrete properties". HBRC Journal, Vol. 8, No 3,pp. 193-203.

[9]. Al-Jabri, K., Taha, R. and Al-Ghassani, M (2005). "Use of copper slag and cement by-pass dust as cementitious materials Cement", Concrete Aggregates, Vol. 24, No.1, pp. 7-12.

[10]. Washington Almeida, Moura Jardel, Pereira Gonc, and Monica Batista Leite Lima (2007). "Copper slag waste as a supplementary cementing material to concrete". J.Mater. Sci., Vol. 42, pp. 2226-2230.

[11]. Binaya Patnaik, Seshadri Sekhar T and Srinivasa Rao (2014). "An Experimental Investigation on Optimum Usage of Copper Slag as Fine Aggregate in Copper Slag admixed Concrete". International Journal of Current Engineering and Technology, Vol.4, No.5. 
[12]. Binaya Patnaik, Seshadri Sekhar T and Srinivasa Rao (2014), "Relationship between the optimum usage of Copper Slag as fine aggregate and Compressive Strength in Copper Slag Admixed Concrete." i-manager's Journal on Civil Engineering, Vol. 4 l No.2 l March - May 2014.

\section{TABLES}

Table 1: Concrete Mix Design Details - M20 \&M30 Mix

\begin{tabular}{|c|c|c|c|c|c|c|c|}
\hline \multirow[b]{2}{*}{ Grade } & \multirow{2}{*}{$\begin{array}{ll}\% & \text { of } \\
\text { Copper } & \\
\text { Slag } & \end{array}$} & \multirow{2}{*}{$\begin{array}{l}\text { Cement in } \\
\mathrm{kg}\end{array}$} & \multicolumn{3}{|c|}{ Fine Aggregate in kg } & \multirow{2}{*}{$\begin{array}{l}20 \mathrm{~mm} \\
\text { Metal in } \\
\text { kg }\end{array}$} & \multirow{2}{*}{$\begin{array}{l}\text { Water in } \\
\mathrm{kg}\end{array}$} \\
\hline & & & $\begin{array}{l}\text { Natural } \\
\text { Sand }\end{array}$ & $\begin{array}{l}\text { Copper } \\
\text { Slag }\end{array}$ & Total FA & & \\
\hline \multirow[b]{2}{*}{ M20 } & $0 \%$ & 320 & 712 & 0 & 712 & 1178 & 176 \\
\hline & $40 \%$ & 320 & 640.8 & 71.2 & 712 & 1178 & 176 \\
\hline \multirow[b]{2}{*}{ M30 } & $0 \%$ & 350 & 703.6 & 0 & 703.6 & 1164 & 175 \\
\hline & $40 \%$ & 350 & 422.16 & 281.44 & 703.6 & 1164 & 175 \\
\hline
\end{tabular}

Table 2: Compressive Strength of M20\& M30 Mix Copper Slag Admixed concrete

\begin{tabular}{|c|c|c|c|}
\hline \multirow[b]{2}{*}{ Grade of Concrete } & \multirow[b]{2}{*}{ Days } & \multicolumn{2}{|l|}{ Compressive Strength (N/mm2) } \\
\hline & & $\begin{array}{ll}\text { 0\% Copper } & \text { Slag } \\
\text { Replacement } & \\
\end{array}$ & $\begin{array}{ll}40 \% \quad \text { Copper } & \text { Slag } \\
\text { Replacement } & \\
\end{array}$ \\
\hline \multirow[b]{2}{*}{ M20 } & 28 & 36.8 & 41.05 \\
\hline & 90 & 44.34 & 55.17 \\
\hline \multirow[b]{2}{*}{ M30 } & 28 & 41.16 & 47.41 \\
\hline & 90 & 51.28 & 57.24 \\
\hline
\end{tabular}

Table 3: Split Tensile Strength of M20\& M30 Mix Copper Slag Admixed concrete

\begin{tabular}{|l|l|l|l|}
\hline \multirow{4}{*}{ Grade of Concrete } & \multicolumn{3}{|l|}{ Split Tensile Strength (N/mm2) Copper Slag } \\
\cline { 3 - 4 } & Days & $\begin{array}{l}\text { 0\% } \\
\text { Replacement } \\
\text { Replacement }\end{array}$ \\
\hline \multirow{3}{*}{ M20 } & 28 & 2.171 & 2.204 \\
\hline \multirow{3}{*}{ M30 } & 90 & 2.39 & 2.58 \\
\hline
\end{tabular}

Table 4: Flexural Strength of M20\& M30 Mix Copper Slag Admixed concrete

\begin{tabular}{|l|l|l|l|}
\hline \multirow{4}{*}{ Grade of Concrete } & \multicolumn{3}{|c|}{ Flexural Strength (N/mm2) } \\
\cline { 3 - 4 } & Days & $\begin{array}{l}\text { 0\% Copper Slag } \\
\text { Replacement }\end{array}$ & $\begin{array}{l}\text { 40\% Copper } \\
\text { Replacement }\end{array}$ \\
\hline \multirow{3}{*}{ M20 } & 28 & 4.44 & 4.747 \\
\hline \multirow{3}{*}{ M30 } & 90 & 5.31 & 5.74 \\
\hline
\end{tabular}

Table 5: Percentage Loss of Weight of Copper Slag Admixed concrete

\begin{tabular}{|c|c|c|c|c|c|c|c|}
\hline \multirow{2}{*}{$\begin{array}{l}\text { Grade of } \\
\text { Concrete }\end{array}$} & \multirow{2}{*}{$\begin{array}{l}\% \text { of } \\
\text { Copper } \\
\text { Slag }\end{array}$} & \multicolumn{2}{|c|}{$10 \%$ HCl Solution } & \multicolumn{2}{|c|}{$10 \%$ Na2So4 Solution } & \multicolumn{2}{|c|}{ 10\% H2So4 Solution } \\
\hline & & 28 days & 56 days & 28 days & 56 days & 28 days & 56 days \\
\hline M20 & $0 \%$ & 7.695 & 10.03 & 0 & 0 & 19.68 & 22.35 \\
\hline
\end{tabular}




\begin{tabular}{|l|l|l|l|l|l|l|l|} 
M20 & $40 \%$ & 6.629 & 8.83 & 0 & 0 & 13.16 & 14.92 \\
\hline M30 & $0 \%$ & 3.750 & 6.64 & 0 & 0 & 13.985 & 17.01 \\
\hline M30 & $40 \%$ & 2.769 & 3.73 & 0 & 0 & 7.409 & 11.27 \\
\hline
\end{tabular}

Table 6: Percentage Loss of Compressive Strength of Copper Slag Admixed concrete

\begin{tabular}{|c|c|c|c|c|c|c|c|}
\hline \multirow{2}{*}{$\begin{array}{l}\text { Grade of } \\
\text { Concrete }\end{array}$} & \multirow{2}{*}{$\begin{array}{l}\% \text { of } \\
\text { Copper } \\
\text { Slag }\end{array}$} & \multicolumn{2}{|c|}{$10 \%$ HCI Solution } & \multicolumn{2}{|c|}{ 10\% Na2So4 Solution } & \multicolumn{2}{|c|}{ 10\% H2So4 Solution } \\
\hline & & 28 days & 56 days & 28 days & 56 days & 28 days & 56 days \\
\hline M20 & $0 \%$ & 8.23 & 27.39 & 0 & 0 & 19.02 & 38.21 \\
\hline M20 & $40 \%$ & 41.42 & 53.25 & 0 & 0 & 51.38 & 64.99 \\
\hline M30 & $0 \%$ & 11.13 & 28.16 & 0 & 0 & 21.55 & 39.19 \\
\hline M30 & $40 \%$ & 42.73 & 61.13 & 0 & 0 & 53.15 & 67.14 \\
\hline
\end{tabular}

\section{GRAPHS}

Compressive Strength of M20 \& M30 Mix Copper Slag Admixed Concrete

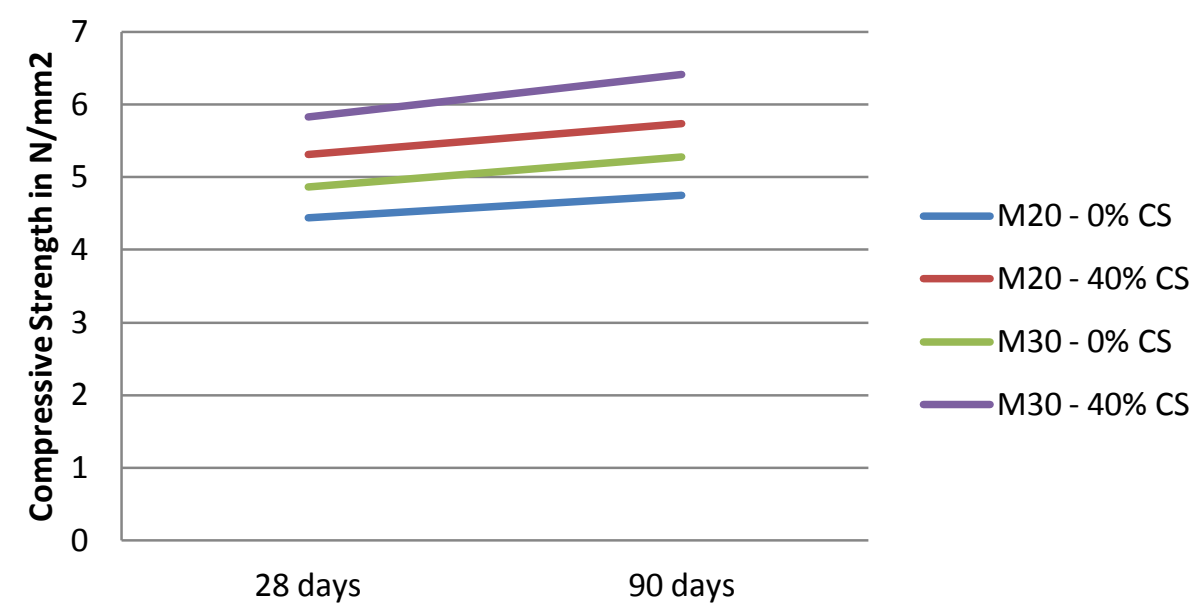

Fig. 1: Compressive Strength - M20 \& M30 Grade Mix with0 \% and $40 \%$ of Copper Slag Replacement at 28 and 90 days

Split Tensile Strength of M20 \& M30 Mix Copper Slag Admixed

Concrete

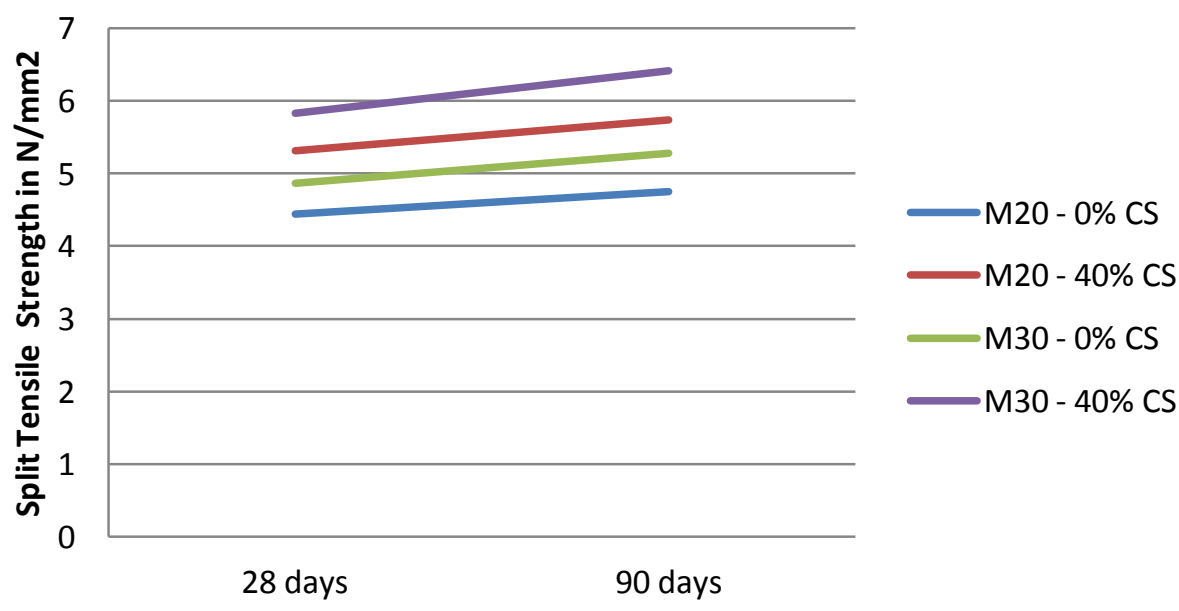

Fig. 2: Split Tensile Strength - M20 \& M30 Grade Mix with0 \% and $40 \%$ of Copper Slag Replacement at 28 and 90 days 


\section{Flexural Strength of M20 \& M30 Mix Copper Slag Admixed Concrete}

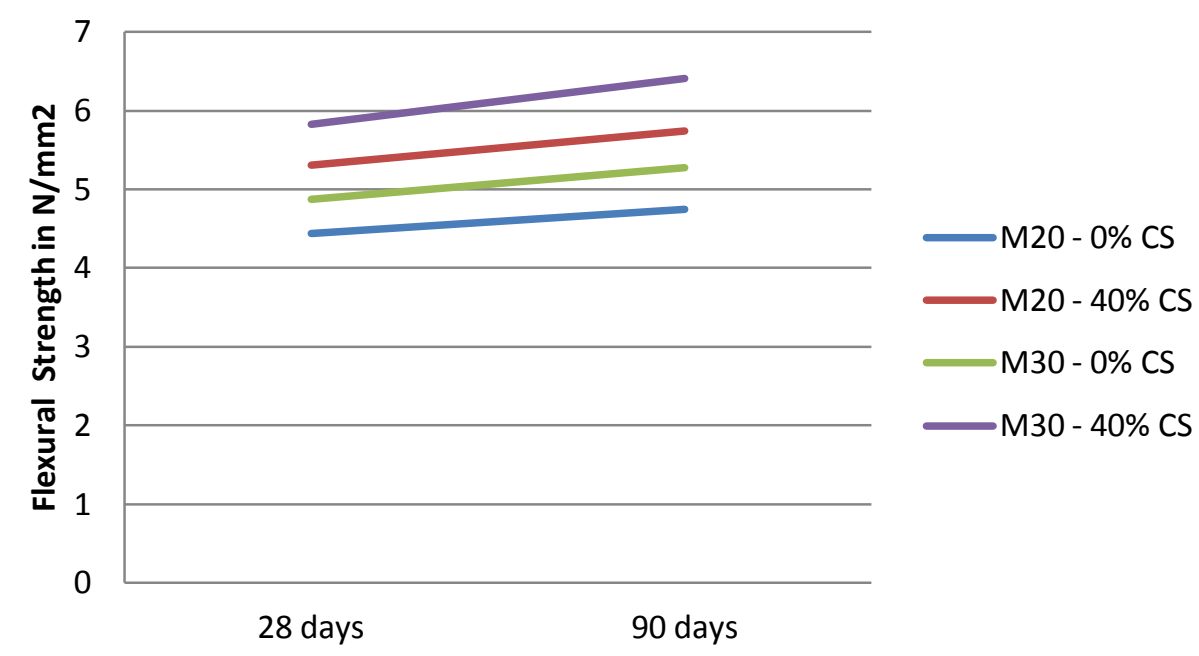

Fig. 3: Flexural Strength - M20 \& M30 Grade Mix with0 \% and $40 \%$ of Copper Slag Replacement at 28 and 90 days

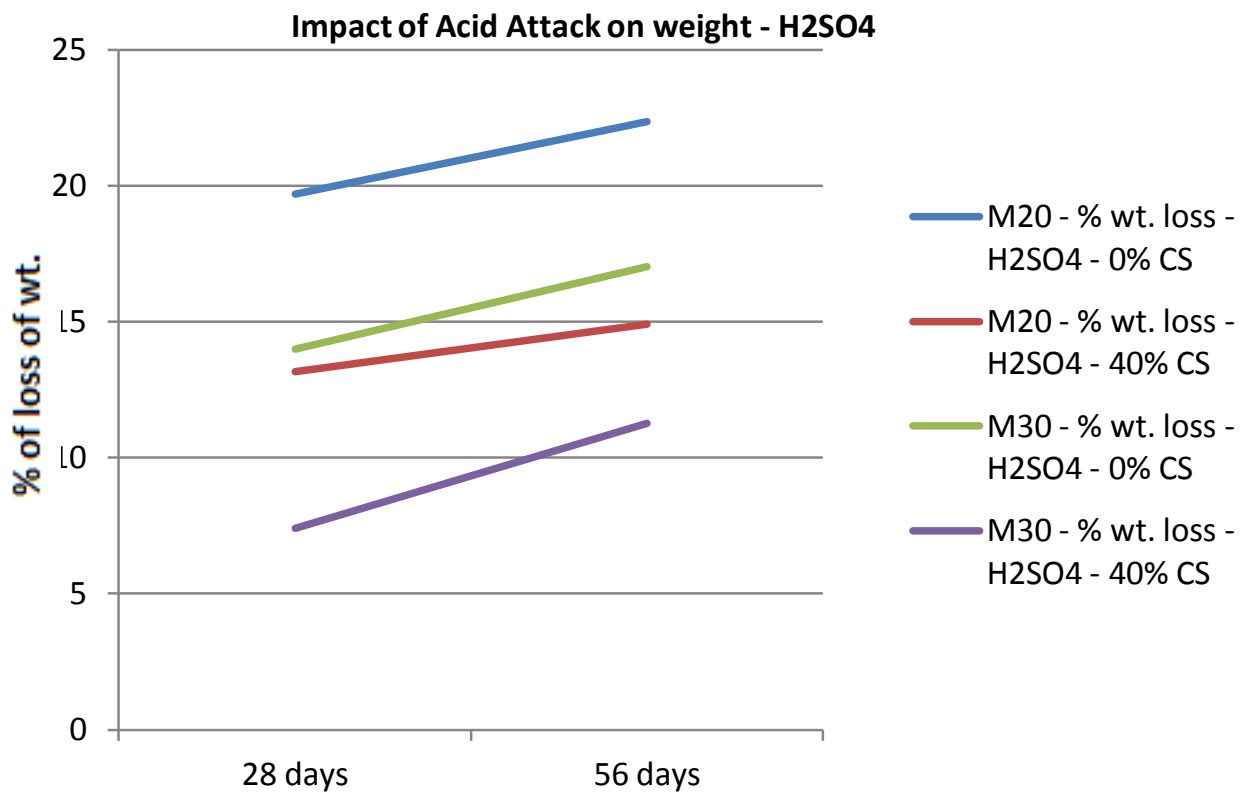

Fig. 4: Impact of Acid Attack (H2SO4) on weight - M20 \& M30 Grade Mix with $0 \%$ and $40 \%$ of Copper Slag Replacement at 28 and 56 days 


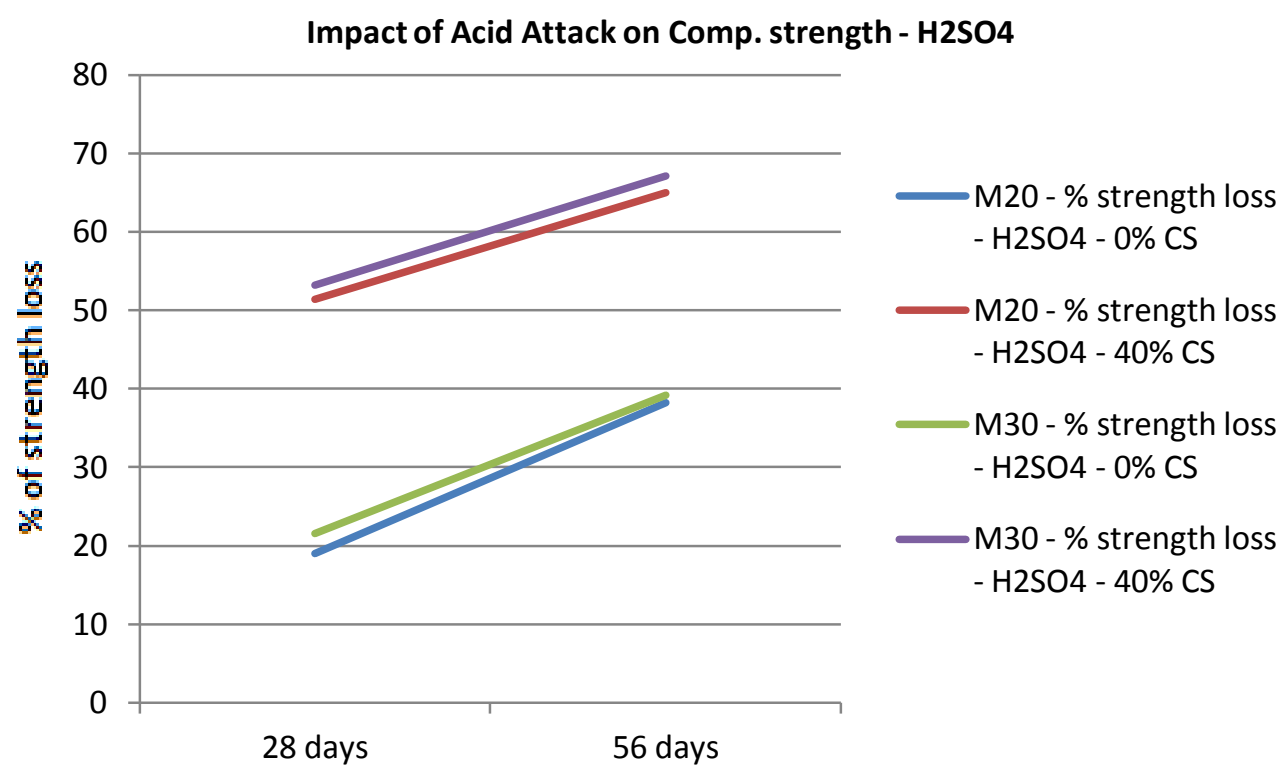

Fig. 5: Impact of Acid Attack (H2SO4) on Compressive Strength - M20 \& M30 Grade Mix with $0 \%$ and $40 \%$ of Copper Slag Replacement at 28 and 56 days.

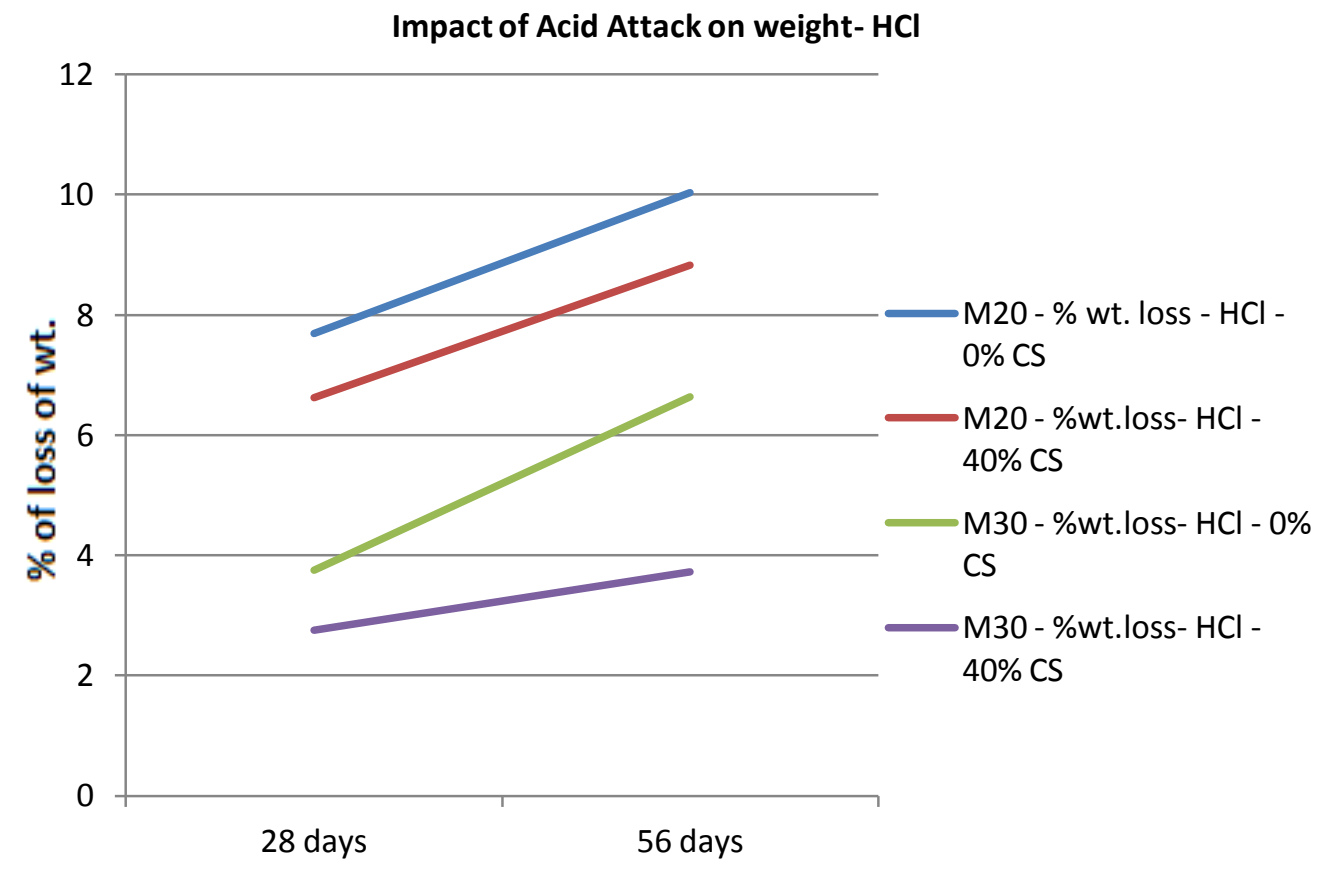

Fig. 6: Impact of Acid Attack (HCl) on weight - M20 \& M30 Grade Mix with $0 \%$ and $40 \%$ of Copper Slag Replacement at 28 and 56 days 


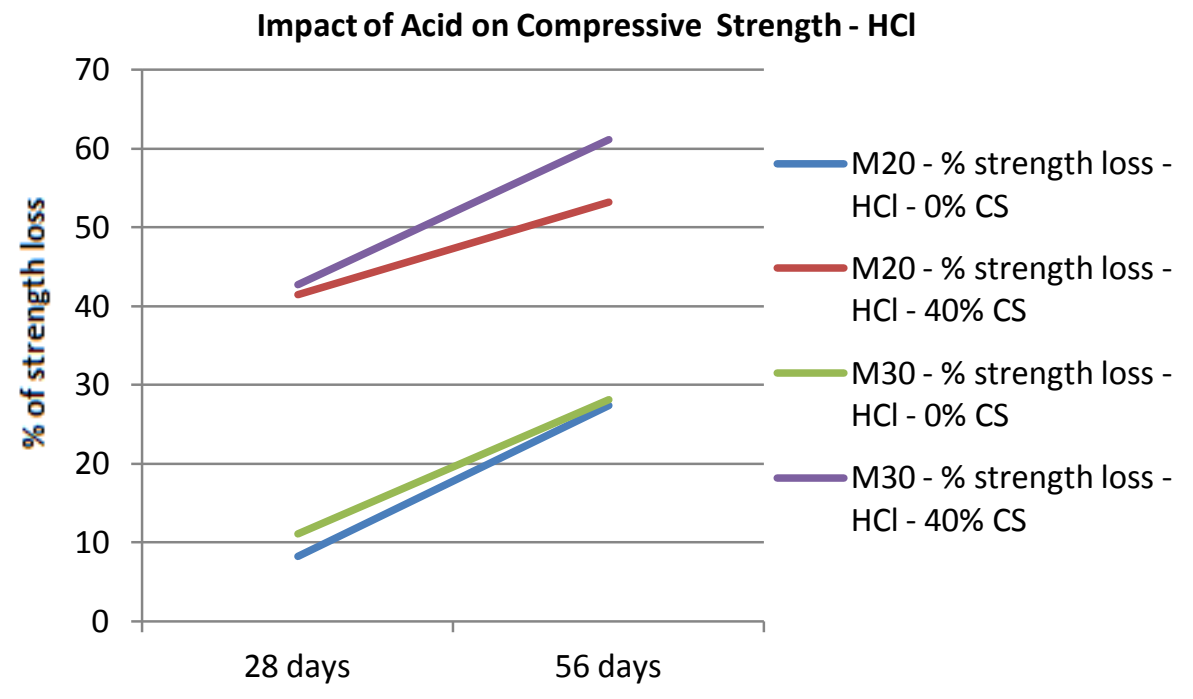

Fig. 7: Impact of Acid Attack (HCl) on Compressive Strength - M20 \& M30 Grade Mix with $0 \%$ and $40 \%$ of Copper Slag Replacement at 28 and 56 days

\section{BIOGRAPHIES}

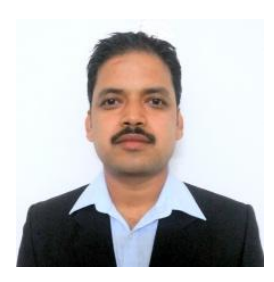

Binaya Patnaik, Research Scholar, GITAM University, Hyderabad. Specialization in Structural Engineering. Has 16 years of research, academic, and industrial experience. Research interests are HPC, Special Concretes and Concrete Technology

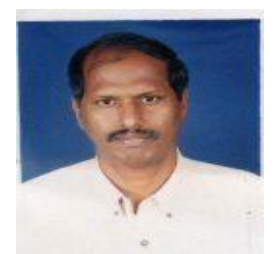

Dr. P. Srinivasa Rao, Professor, JNTU college of Engineering, JNTUH. Specialization in Structural Engineering. Research Interests are Design of Structures, HPC, Concrete Technology \& Special Concrete. Has 25 years of industrial, research and academic experience. Has guided 100 M.Tech and $4 \mathrm{PhD}$ students.

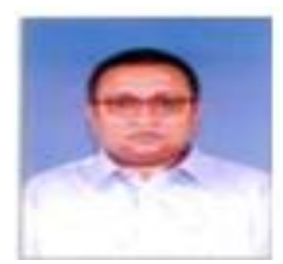

Dr. Seshadri Sekhar.T, Professor and Head Department of Civil Engineering, GITAM University, Hyderabad. Specialization in Structural Engineering. Research Interests are Concrete Technology, Special Concrete, HPC and Special Concrete. Has 24 years of industrial, research and academic experience. Has guided 25 M.Tech and $6 \mathrm{PhD}$ students. 